\title{
TINDAKAN REPRODUKSI SEHAT PADA REMAJA DI SMAN 1 SUNGGAL KABUPATEN DELI SERDANG
}

\author{
Dina Indarsita \\ Jurusan Keperawatan Poltekkes Kemenkes Medan
}

\begin{abstract}
Abstrak
Reproduksi remaja yang sehat bukan hanya bebas dari penyakit atau kecacatan, namun juga sehat secara mental. Angka kejadian kehamilan diluar nikah meningkat ditandai dengan meningkatnya kasus aborsi yang diperkirakan setiap tahun ada 2,3 juta kasus aborsi, yang 20 persen diantaranya dilakukan remaja, berdasarkan penelitian Perkumpulan Kelurga Berencana Indonesia (PKBI), sebanyak 27 persen permintaan aborsi tidak aman dilakukan remaja. Sementara itu, menurut Muadz, 2007 penularan penyakit kelamin seperti HIV/AIDS tercatat sampai bulan Maret 2007 terdapat 8.988 kasus AIDS dan 5.640 kasus HIV positif. Dari delapan ribu atau 57, 1 persen kasus HIV/AIDS terjadi pada remaja antar 15-29 tahun. Kurangnya pengetahuan tentang reproduksi sehat kepada remaja dapat membentuk sikap dan tingkah laku yang tidak bertanggung jawab mengenai proses reproduksi. Penelitian ini bertujuan untuk mengetahui gambaran tindakan reproduksi sehat pada remaja di SMA N I Sunggal Kabupaten Deli Serdang. Manfaat penelitian ini agar remaja tahu bagaimana tindakan reproduksi sehat. Penelitian ini bersifat deskriptif dengan desain Cross Sectional. Pengumpulan data menggunakan kuesioner tentang tindakan reproduksi sehat yang diberikan kepada lebih kurang 134 orang siswa kelas tiga IPA SMA N I Sunggal Kabupaten Deli Serdang. Penelitian mulai dari tanggal 22 Agustus 2015. Selanjutnya data diolah dengan menggunakan sistem komputerisasi dengan tingkat signifikansi $95 \%(0,05)$. Hasil penelitian ini didapatkan bahwa ada 32 orang $(58,2 \%)$ siswa laki laki dan 48 orang $(60,76 \%)$ siswa perempuan yang mempunyai tindakan reproduksi yang baik. Saran Perawat agar lebih aktif memberikan informasi mengenai tindakan reproduksi sehat melalui pemberian penyuluhan tindakan reproduksi sehat kepada remaja dengan menggunakan leaflet atau pun konseling kesehatan reproduksi dan pengelola SMA N I Sunggal Kabupaten Deli Serdang lebih meningkatkan kegiatan UKS agar informasi tentang kesehatan reproduksi tersampaikan dengan baik dan benar dengan tujuan agar siswa mampu melakukan tindakan reproduksi sehat.
\end{abstract}

Kata Kunci : Pengetahuan Reproduksi Sehat, Tindakan Reproduksi Sehat

\section{PENDAHULUAN}

Kesehatan reproduksi tidak hanya berbicara tentang menjaga fisik organ reproduksi semata tapi juga menyangkut aspek emosi dan sosial masyarakat. Karena pengertian sehat disini bukan hanya bebas dari penyakit atau kecacatan, namun juga sehat secara mental. Maka itu, memang diperlukan waktu yang tepat untuk memberikan pengetahuan mengenai kesehatan reproduksi. Dengan kurangnya pengetahuan kesehatan reproduksi kepada remaja dapat membentuk sikap dan tingkah laku yang tidak bertanggung jawab mengenai proses reproduksi untuk mendapatkan reproduksi sehat dan menyebabkan mereka tidak mengetahui bahwa ada risiko kehamilan di luar nikah dan penularan penyakit kelamin (Laurike, 2003).

Jumlah remaja di Indonesia yang berusia 10-24 tahun mencapai 65 juta orang atau 30 persen dari total penduduk Indonesia, 15-20 persen dari remaja tersebut sudah melakukan seks bebas (Perdana, 2007). Sedangkan jumlah remaja di Sumatera Utara yang berusia 15 tahun keatas pada tahun 2007 mencapai 8.287.473 jiwa atau 68 ,
15 persen (Okanegara, 2008).

Hasil penelitian dari 362 responden didapatkan hanya 24 persen yang memiliki pengetahuan baik mengenai organ reproduksi perempuan, dan hanya 23 persen yang memiliki pengetahuan yang baik mengenai organ reproduksi laki-laki, hal ini menyebabkan ketidaktahuan remaja mengenai organ reproduksi dan cara perawatannya, hanya sekitar 11,3 persen remaja perempuan yang mengetahui cara perawatan organ reproduksinya dan 6,4 persen remaja laki-laki yang mengetahui cara perawatan organ reproduksinya. Dengan memiliki pengetahuan mengenai sistem reproduksi, maka diharapkan remaja dapat mengetahui cara merawat organ reproduksinya sehingga dapat terhindar dari gangguan saluran reproduksi serta memiliki sikap dan tingkah laku yang bertanggung jawab mengenai proses reproduksi termasuk mencegah kehamilan diluar nikah dan penularan penyakit kelamin (Husni, F. 2005).

Angka kejadian kehamilan diluar nikah meningkat ditandai dengan meningkatnya kasus aborsi yang diperkirakan setiap tahun ada 2,3 juta kasus aborsi, yang 20 persen diantaranya dilakukan remaja, berdasarkan 
penelitian Perkumpulan Kelurga Berencana Indonesia (PKBI), sebanyak 27 persen permintaan aborsi tidak aman dilakukan remaja. Sementara itu, penularan penyakit kelamin seperti HIV/AIDS tercatat sampai bulan Maret 2007 terdapat 8.988 kasus AIDS dan 5.640 kasus HIV positif. Fatalnya, sekitar delapan ribu atau 57, 1 persen kasus HIV/AIDS terjadi pada remaja antar 15-29 tahun (Muadz, 2007).

Hasil penelitian yang telah dilakukan menyatakan bahwa kurangnya perilaku higienis saat menstruasi dapat menyebabkan berbagai penyakit misalnya kanker rahim. Menurut beberapa penelitian menyebutkan bahwa kanker ini disebabkan oleh virus Human Papilloma Virus (HPV) yang muncul, antara lain karena perilaku tidak higienis pada saat menstruasi. Virus ini hidup di daerah yang lembab, persisnya dalam cairan vagina yang diidap oleh penderita keputihan (leukore). Jika keputihan ini tidak segera membaik, virus ini bisa memunculkan kanker rahim. Biasanya keadaan ini ditandai dengan banyaknya cairan keputihan yang disertai bau tidak sedap dan perdarahan yang keluar dari vagina.

Berdasarkan data diatas penulis ingin meneliti tentang "Tindakan reproduksi sehat pada remaja di SMAN I Sunggal Kabupaten Deli Serdang”.

\section{Perumusan masalah}

Bagaimana tindakan reproduksi sehat pada remaja di SMAN I Sunggal Kabupaten Deli Serdang?

\section{TUJUAN}

\section{Tujuan Penelitian}

a. Mengetahui gambaran tindakan reproduksi sehat pada remaja laki-laki.

b. Mengetahui gambaran tindakan reproduksi sehat remaja perempuan.

\section{Urgensi (Keutamaan) Penelitian}

1 Bagi Remaja

Dapat menambah informasi mengenai reproduksi sehat

2 Bagi Tempat Penelitian

a. Dapat mengetahui gambaran tindakan reproduksi sehat .

b. Dapat meningkatkan pendidikan tentang reproduksi sehat disekolah.

3 Bagi Peneliti Selanjutnya

Dapat menjadi bahan bacaan dan referensi untuk penelitian lebih lanjut.

\section{METODA}

\section{Rancangan dan Desain Penelitian}

Penelitian ini adalah penelitian deskriptif dengan pendekatan cross sectional untuk mengetahui gambaran tindakan reproduksi sehat pada remaja di SMA N I Sunggal Kabupaten Deli Serdang.

\section{Populasi dan Sampel Penelitian}

1 Populasi

Populasi dalam penelitian ini adalah seluruh siswa (Laki-laki dan Perempuan) SMA N I Kelas IPA Sunggal Kabupaten Deli Serdang tahun 2015 sebanyak = 531 orang terdiri dari Kelas $X=225$ orang ( $L k=85$, $\mathrm{Pr}=140), \quad \mathrm{XI}=159$ orang $(\mathrm{Lk}=62, \mathrm{Pr}=98), \mathrm{XII}=147$ orang $(\mathrm{Lk}=59, \mathrm{Pr}=86)$

\section{Sampel}

Tehnik pengambilan sampel dalam penelitian ini adalah sampling jenuh. Sampelnya yaitu semua siswa kelas XII jurusan IPA SMA N I Sunggal Kabupaten Deli Serdang sebanyak 147 orang (Laki laki $=59$, Perempuan $=86$ )

\section{Lokasi Penelitian}

Penelitian ini dilakukan di SMA N I Sunggal Kabupaten Deli Serdang yang dilakukan pada Minggu I Bulan September 2015.

Lokasi ini dipilih karena :

a. SMA N I Sunggal Kecamatan Deli Serdang adalah satu lembaga pendidikan formal dibawah naungan pemerintah yang memiliki kualitas yang bagus dan memberikan peluang agar dimasuki dan dikaji oleh peneliti sebagai obyek penelitian.

b. SMA N I Sunggal Kecamatan Deli Serdang adalah salah satu sekolah yang mengirimkan siswa untuk belajar di Poltekkes kemenkes Medan melalui jalur undangan.

c. Sekolah yang sudah mempunyai KRR (Kesehatan Reproduksi Remaja) dan program UKS (Usaha kesehatan Sekolah).

\section{Pertimbangan Etik}

Dalam pengambilan data ini, peneliti akan membuat informed consent, yaitu persetujuan untuk menjadi responden, dan ditanda tangani oleh responden, kuesioner tidak mencantumkan nama responden (anonimity), jawaban yang diberikan responden adalah jawaban sendiri tanpa dipengaruhi oleh siapapun dan akan dijaga kerahahasiaannya (confidentiality).

\section{HASIL}

\section{Hasil Penelitian}

Berdasarkan hasil pengumpulan data yang dilakukan pada Minggu I Bulan September 2015 mengenai Tindakan Reproduksi Sehat pada remaja di SMA N I Sunggal Kabupaten Deli Serdang Tahun 2015 dengan jumlah responden 134 orang, diperoleh data sebagai berikut:

1. Distribusi Frekuensi Menurut Jenis Kelamin

Tabel 1: Distribusi Frekuensi Siswa Menurut Jenis Kelamin di SMA N I Sunggal Kabupaten Deli Serdang Tahun 2015

\begin{tabular}{cccc}
\hline No & Jenis Kelamin & Jumlah & Persentase (\%) \\
\hline 1. & Laki-laki & 55 & 41 \\
2. & Perempuan & 79 & 59 \\
\hline & Jumlah & $\mathbf{1 3 4}$ & $\mathbf{1 0 0}$
\end{tabular}


Berdasarkan tabel 1 diatas dapat dilihat bahwa dari 134 responden yang menjadi subyek penelitian kebanyakan berjenis kelamin perempuan yaitu sebanyak 79 orang (59\%), dan lebih sedikit siswa berjenis kelamin laki-laki yaitu sebanyak 55 orang $(41 \%)$.

\section{Tindakan Reproduksi sehat}

Tabel 2: Distribusi frekuensi tindakan reproduksi sehat siswa laki-laki di SMA N I Sunggal Kabupaten Deli Serdang Tahun 2015

\begin{tabular}{|c|c|c|}
\hline Tindakan & Jumlah & $\%$ \\
\hline Kurang baik & 23 & 41,8 \\
\hline Baik & 32 & 58,2 \\
\hline Jumlah & 55 & 100 \\
\hline
\end{tabular}

Berdasarkan tabel 2 diatas terlihat bahwa dari 55 responden yang tindakan reproduksi nya kurang baik sebanyak 23 orang (41.8\%) dan yang tindakan reproduksinya baik sebanyak 32 orang $(58,2 \%)$.

Tabel 3: Distribusi frekuensi tindakan reproduksi sehat siswa Perempuan di SMA N I Sunggal Kabupaten Deli Serdang Tahun 2015

\begin{tabular}{|c|c|c|}
\hline Tindakan & Jumlah & $\%$ \\
\hline Kurang baik & 31 & 39,24 \\
\hline Baik & 48 & 60,76 \\
\hline Jumlah & 79 & 100 \\
\hline
\end{tabular}

Berdasarkan tabel 3 diatas terlihat bahwa dari 79 siswa tindakan reproduksi nya yang kurang baik sebanyak 31 orang $(39.24 \%)$ dan kategori tindakan baik sebanyak 48 orang $(60,76 \%)$.

\section{Pembahasan}

\section{Tindakan Reproduksi Sehat Remaja laki laki}

Dari hasil analisa data diketahui bahwa 32 orang $(58,2 \%)$ siswa laki laki mempunyai tindakan reproduksi yang baik.

Hal ini didukung oleh ada 54 orang (98\%) yang selalu mencucitangan sebelum dan sesudah BAK, 53 orang $(96 \%)$ yang selalu mengganti pakaian dalam jika basah, ada 50 orang $(91 \%)$ yang selalu membersihkan alat kelamin setelah buang air kecil (BAK) menggunakan air mengalir.

\section{Tindakan Reproduksi Sehat Remaja Perempuan}

Dari hasil analisa data diketahui bahwa 48 orang $(60,76 \%)$ siswa perempuan mempunyai tindakan reproduksi yang baik.

Hal ini didukung oleh ada 72 orang siswa perempuan $(91,1 \%)$ yang selalu mencuci tangan sebelum dan sesudah BAK, ada 71 orang $(89,9 \%)$ yang selalu membersihkan alat kelamin setelah $\mathrm{BAB}$ dan BAK, ada 65 orang $(82,3 \%)$ yang selalu membersihkan alat kelamin setelah BAB dan BAK.

Hasil penelitian diatas menunjukkan bahwa ada 32 orang $(58,2 \%)$ siswa laki laki dan 48 orang $(60,76 \%)$ siswa perempuan yang mempunyai tindakan reproduksi yang baik artinya remaja mulai melaksanakan atau mempraktekkan apa yang diketahui atau disikapi (dinilai baik) mengenai reproduksi sehat.

Menurut Utamadi (2007), tindakan reproduksi sehat yaitu memiliki kemampuan untuk melindungi diri mereka sendiri dari berbagai penyakit serta kehamilan yang tidak dikehendaki, sadar akan sikap dan perilaku seksual mereka. Mereka juga percaya bahwa mengembangkan reproduksi sehat adalah bagian dari upaya hidup sehat. Untuk mendapatkan reproduksi sehat kita harus dapat merawat dan menjaga tubuh kita dengan baik.

Pengetahuan dan kemampuan merawat organ reproduksi juga merupakan hal yang sangat penting dalam upaya mendapatkan reproduksi sehat.

Tindakan siswa yang baik ini sesuai dengan pendapat Notoatmodjo (2003) bahwa setelah seseorang mengetahui stimulus atau objek, kemudian mengadakan penilaian atau pendapat terhadap apa yang diketahui, proses selanjutnya diharapkan ia akan melaksanakan atau mempraktekkan apa yang diketahui atau disikapi (dinilai baik).

\section{SIMPULAN}

Hasil dari penelitian yang diperoleh mengenai Tindakan reproduksi sehat siswa SMA N I Sunggal Kabupaten Deli Serdang, diperoleh kesimpulan sebagai berikut:

Ada 32 orang $(58,2 \%)$ siswa laki laki dan 48 orang $(60,76 \%)$ siswa perempuan yang mempunyai tindakan reproduksi yang baik.

\section{SARAN}

Berdasarkan hasil penelitian mengenai tindakan reproduksi sehat pada remaja di SMA N I Sunggal Kabupaten Deli Serdang, maka disarankan:

1. Bagi profesi tenaga kesehatan khususnya perawat maternitas

Agar lebih aktif memberikan informasi mengenai kesehatan reproduksi dan tindakan reproduksi sehat melalui kegiatan pengabdian kepada masyarakat yakni memberikan demonstrasi / penyuluhan kesehatan reproduksi kepada remaja dengan menggunakan leaflet atau pun konseling kesehatan reproduksi.

2. Bagi Profesi Pendidik

Agar bekerja sama dengan instansi pendidikan kesehatan dalam hal pemberian informasi tentang kesehatan reproduksi.

3. Bagi SMA N I Sunggal Kabupaten Deli Serdang Agar SMA N I Sunggal Kabupaten Deli Serdang lebih meningkatkan kegiatan UKS dan KRR agar informasi tentang kesehatan reproduksi tersampaikan dengan baik dan benar dengan tujuan siswa mampu untuk merawat organ reproduksi. Reproduksi yang sehat adalah merupakan bagian dari hidup sehat.

4. Bagi Siswa

Agar berusaha mendapatkan informasi tentang kesehatan reproduksi sehingga mampu melakukan 
tindakan reproduksi sehat antara lain aktif mengikuti kegiatan UKS dan KRR di sekolah.

5. Bagi Peneliti Selanjutnya

Sebagai bahan masukan yang nantinya, dapat digunakan sebagai referensi untuk melakukan penelitian lanjutan yang lebih mendalam tentang aktifitas remaja dalam hal Reproduksi Sehat.

\section{DAFTAR PUSTAKA}

Agustiani, H. 2006. Psikologi Perkembangan. Bandung: Refika Aditama.

Arikunto, S. 1998. Prosedur Penelitian. Yogyakarta: Rineka Cipta.

BKKBN, 2014 Kependudukan Indonesia Alami Triple Burden http://www.bkkbn.go.id/ViewBerita.aspx?BeritaID $=1030$

Coad, J. 2006. Anatomi dan Fisiologi Untuk Bidan. Jakarta: EGC.

Cunningham, G dkk. 2005. Obstetri Williams. Jakarta: EGC.

Depkes RI. 1991. Kumpulan Materi Kesehatan Reproduksi Remaja. Jakarta: Departemen Kesehatan.

Hidayat, A. 2007. Metode Penelitian Kebidanan dan Teknik Analisa Data. Jakarta: Salemba Medika.

Husni, F. 2005. Pendidikan Kesehatan Reproduksi Remaja. Http://osdir.com. (dikutip tanggal 19 Juni 2008).

Imelda, I. Menjaga Kesehatan Reproduksi. Http://maduhighdesert.blogspot.com. (dikutip tanggal 14 Desember 2007).

Ira Analita. 2009. Hubungan pengetahuan dan sikap perawat dalam intervensi

keperawatan pada bayi resiko hipotermi Diruang Neonatologi RSUP

Dr. Soetomo Airlangga. Skripsi tidak diterbitkan, Surabaya: Fakultas

Kedokteran - Univesrsitas.

Laurike. 2003. Pentingnya Pemahaman Kesehatan Reproduksi. Http://www.aidsindonesia.or.id. (dikutip tanggal 13 Desember 2007).

Manuaba, IBG. 1998. Ilmu Kebidanan, Penyakit Kebidanan dan Keluarga Berencana Untuk Pendidikan Bidan. Jakarta: EGC.

1999. Memahami Kesehatan Reproduksi Wanita. Jakarta: Arcan.

Mochtar, R. 1998. Sinopsis Obstetri: Obstetri Fisiologi, Obstetri Patologi. Jakarta: EGC.

Mohammad, K. 1998. Kesehatan Reproduksi. Jakarta: Pustaka Sinar Harapan.
Muadz, M. 2007. Remaja dan Perlindungan Hak Reproduksi. Http://www.bkkbn.id. (dikutip tanggal 13 Desember 2007).

Musbir, W. 2000. Kesehatan Reproduksi di Indonesia. Medan: IBI.

Mueller. 1986. Mengukur Sikap Sosial. Jakarta: Rineka Cipta.

Notoatmodjo, S. 2003. Ilmu Kesehatan Masyarakat. Jakarta: PT Rineka Cipta.

Okanegara. 2008. Remaja dan Perubahan Biopsikososial. Http://www.bappenas.go.id. (dikutip tanggal 19 Juni 2008).

Perdana, A. 2007. Ironi Sebuah Negeri Muslim. Http://arifperdana.wordpress.com. (dikutip tanggal 13 Desember 2007).

Sarwono. 2000. Psikologi Remaja. Jakarta: PT. Grasindo Persada.

Saputra, Ginto. 2008. Gambaran Pengetahuan, Sikap, dan Perilaku terkait HIV-AIDS pada siswa kelas III SMA PGRI I Kota Bogor Tahun 2008 (Skripsi). Depok : FKM UI

Sudardjat, A. 2002. Hak Remaja Atas Kesehatan Reproduksi. Http://situs.kesrepro.info/krr. (dikutip tanggal 27 September 2007).

Sugiri. 2007. Pergaulan Bebas Mengkhawatirkan. Http://www.hupelita.com. (dikutip tanggal 19 Juni 2008).

Suhartono, S. 2005. Filsafat Ilmu Pengetahuan. Jogjakarta: Ar- Ruzz Media.

Surjadi, C (Peny.). 2001. Kesehatan Reproduksi, Narkoba, dan Kota Sehat. Jakarta: Jaringan Epidemiologi Nasional Badan Litbangkes Depkes RI.

Tanya Jawab Kesehatan Reproduksi Remaja. 2000. Http://www.kelurgasehat.com./kelurga-remajaisi. (dikutip tanggal 29 September 2007).

Utamadi, G. 2007. Kesehatan Seksual. Http://www.pkbi.id. (dikutip tanggal 14 Desember 2007).

Watson, R. 2002. Anatomi dan Fisiologi Untuk Perawat. Edisi 10. Jakarta: EGC.

Winkjosastro, H. 2006. Ilmu Kebidanan. Edisi 3. Jakarta: Yayasan Bina Pustaka Sarwono Prawirohardjo.

Yayasan Pendidikan Kesehatan Perempuan. 2004. Konseling Kesehatan Reproduksi. Jakarta: IBI.

Yusuf LN, S. 2000. Psikologi Perkembangan Anak dan Remaja. Bandung: PT Remaja Rosdakarya. 